with Myrobalan $B$. Barbara Mosse shows that on a tree successfully established on a Brompton rootstock, incompatibility was induced by ring-grafting the Brompton stem with Myrobalan $B$ bark, and the histology of the union is described. Papers on varietal performance and fruit management include two papers by A. P. Preston, on the results of variety trials of black currants over seven years, and an assessment over nine years of two systems of pruning the crop. Dorothy J. Wilson has measured the loss in yield due to the genetic conditions of Auchineruive Climax known as transient yellows and 'streals'. M. M. McNeill finds that apples grown in pots under glass require applications of dried blood to supplement the normal John Innes potting compost. D. W. Way and G. H. Freeman have bravely undertaken a very careful tasting trial of strawberries and raspberries, with results which are, nevertheless, somewhat of a surprise-at least to the present writer. Tempera. tures during night frosts were higher over compacted ground than over loose soil, according to C. H. W. Slater and J. P. Ruxton.

It is important that materials for the control of pests should not themselves cause damage, but H. W. B. Barlow, G. H. L. Dicker and J. B. Briggs found that parathion sprays against apple sawfly caused marked fruit drop. Yet parathion gave more significant increases in yield than gamma-benzene hexachloride and nicotine. Such increases were not due to control of the sawfly, and the mechanism by which they were obtained requires further investigation. H. W. B. Barlow, C. R. Hancock and H. J. Lacey have isolated certain heat-stable growthinhibiting substances from woody shoots of crab $C$ and Myrobalan $B$ rootstocks. Changes in mineral nutrients in the leaves of the 'biennial bearer' apple Miller's Seedling were investigated by A. C. Mason, who has shown that larger concentrations of nitrogen, phosphorus, magnesium, calcium and manganese occur in the fruiting years than in the non-fruiting ones. A laboratory study by E. L. Frick of thirty materials for their relative ability to inhibit spore germination of Botrytis cinerea brought out some interesting divergencies between laboratory and field performance. Two of the substances--tecnazene and pentachlornitrobenzene - are already in use against the fungus, but did not inhibit spore germination. Thiram and the ferric, zinc and manganese dithiocarbamates, moreover, inhibited spore germination at two different concentration ranges.

Leaf roll, a new virus disease of the sweet cherry, is described by A. F. Posnette and R. Cropley. An attempt to clarify the relations between nettlehead and split leaf blotch viruses of hops has been made by $J$. T. Legg. Evidence for the view that the latter is a component of a complex causing the former is as yet inconclusive; but in this particular field trial, the relevant clones of College Cluster and Malling Midseason had the lowest amount of nettlehead of any variety tested. A. M. Massee contributes fifteen short notes on interesting insect records in 1954, perhaps the most important of which is an attack by cockchafers in two localities. He also reviews problems arising from the use of insecticides, and makes a plea for entomologists to study their effects upon the whole orchard fauna. Joan R. Groves reports that mercury-vapour light traps were found more efficient than bait traps for catching codling moths, while D. A. Chant and R. C. Muir find that the brushing machine method is superior to the imprint method for estimating numbers of fruit-tree red-spider mites. In the realm of statistics, G. H. Freeman and Margaret J. Hall point out that variations in number of red-spider mites from leaf to leaf, between trees, and also between plots, should all be considered when estimating the significance of control treatments.

There are, in the report, also accounts of all the activities of research sections and a description of the organization of the experimental farm. There are weather records and the texts of three bulletins for fruit-growers: on the search for better fungicides, by $\mathbf{M}$. H. Moore ; an illustrated description of capsid bugs, by Elsie Collyer; and on some impressions of apple orchard practices in Canada, by G. H. L. Dicker and A. H. M. Kirby. The volume is produced to the usual high standards of printing and illustration, and--most welcome-there is an index.

John Grainger.

\section{PATHOLOGY OF BIRDS IN ZOOLOGICAL GARDENS}

$\mathrm{A}$

STUDY of the pathology of birds in the Zoological Gardens of Antwerp has been made by Prof. L. M. G. Geurden, of the University of Ghent (Bulletins de la Société Royale de Zoologie, d'Anvers, No. 4).

Bird diseases in zoological gardens are numerous and mortality is very high. The primary cause may be either in the country of origin or in the transportation, or in the zoological garden itself. In captivity, malnutrition, deficient food or lack of movement influence a large number of birds, although their susceptibility varies within wide limits from one individual to another.

In the period under review, Prof. Geurden dissected thirty-five dead birds; a laboratory analysis was often required for a definitive diagnosis. The most common causes of death were pneumonia (5), visceral gout (13) and hæmorrhagic enteritis (22). Pneumonia, quickly followed by death, is common in birds originating from tropical countries when exposed to low temperature. Isosporosis involving a primary disease is likewise very frequent. Captive birds often suffer from visceral gout; the great change in the way of living and in the nature of the food is doubtless the starting-point of this disease, although the susceptibility of different individuals varies considerably. Diseases such as cæcal coccidiosis and black head will affect all members of the gallinaceous group in the same way.

The majority of birds had died from hæmorrhagic enteritis. In the absence of intestinal parasites, the bacteriological test for detecting Salmonellae often shows a negative result. Salmonellae were cultivated seven times from the intestinal contents.

Birds are commonly considered as the biggest reservoir of Salmonellae; powdered eggs used during the War have shown this on a very large scale. In some cases latent infections occur, in others acute diseases develop. Although several internal organs may be the seat of these infections, they are more often found in the intestines and in the genital organs. Owing to the large number of Salmonella-types, the epidemiology of Salmonella-infections is quite confused, and, in his work, Prof. Geurden clarifies a number of points which have previously caused difficulties with various species and types. 